\title{
Development Assistance and Geopolitics in Australia-China-Taiwan Relations*
}

\author{
JOEL ATKINSON**
}

The development assistance programs of Australia, China and Taiwan impact each other's geopolitical interests in the South Pacific region. This "aid triangle" has recently undergone a significant transformation. Previously, the interests of Australia and China aligned in competing against Taiwan for political influence in the region. However, since 2008, China-Taiwan relations have warmed and their aid contest in the South Pacific has been largely put on hold. This has ameliorated Taiwan's conflict with Australia, and the two countries have increased their development assistance cooperation. However, China's role in undermining Australia's policy towards Fiji, and the global deterioration in China's relations with a US coalition (including Australia), have potentially increased the competitive aspects of the Sino-Australian side of the triangle.

Keywords: Foreign Policy, International Relations, Politics, Pacific, Development, Oceania, Aid, ODA

* Work on this article began when the author was a lecturer with the Chinese Studies program at Monash University in Melbourne, Australia.

** Research Fellow, Institute for Poverty Alleviation and International Development, Yonsei University, South Korea; E-mail: Joel.Atkinson@yonsei.ac.kr

DOI: 10.16934/isr.16.2.201512.1 


\section{INTRODUCTION}

Development assistance is a key link in the mutual relations of Australia, China and Taiwan. China's opposition to Taiwan independence sees most countries, including Australia, shy away from officially recognizing Taiwan. To counter some of this pressure, Taiwan provides aid in return for the diplomatic recognition of small developing countries such as the island states in the South Pacific. China delivers aid of its own to stop these countries from recognizing Taiwan. Both sides in this diplomatic competition undermine Australia's policy of using conditional aid to reform South Pacific governance. However, China's power to help and hurt Australian interests, and Taiwan's relative weakness, saw Australia direct its hostility largely towards Taiwan. So while the interests of Australia and China are quite different, they nevertheless aligned in contesting Taiwan's aid-related influence in the South Pacific. Crucially, the opposition Kuomintang (Chinese Nationalist party, KMT) in Taiwan also shared this interest in frustrating the Democratic Progressive Party (DPP) administration of Chen Shui-bian (20002008). The KMT would use its influence and control of the legislature to significantly increase the pressure on President Chen.

This alignment of Chinese, Australian, and domestic pressure on Chen Shuibian and the DPP is crucial to understanding the current pattern of their mutual aid cooperation and competition. The tacit "diplomatic truce" the incoming Ma Yingjeou administration was able to secure with Beijing should be understood as a joint KMT and Chinese government attempt to demonstrate to Taiwanese voters the KMT's superior ability to maintain diplomatic relationships, reduce foreign affairs expenses and improve relations with Western democracies such as Australia. The truce has indeed ameliorated Taiwan's conflict with Australia, and the two countries have increased their aid cooperation in important ways. On the other hand, and reflecting that for China the truce is about Taiwan not Australia or the South Pacific, China has not sought to improve Sino-Australian relations through the truce, and South Pacific friction between Australia and China has potentially increased. This appears to have contributed to an easing of Australia's policy of prioritizing governance in its relations with the South Pacific.

The article begins with a background of the Australia-China-Taiwan aidrelated relations in the South Pacific. It then examines the significant changes Taiwan has - and has not - made to its aid program after the establishment of the diplomatic truce, and the impact on its relations with Australia and the Pacific Islands. Next, the article looks at how China views the truce in the context of its relations with Taiwan, the South Pacific and Australia. It then discusses indications of increasing friction between China and Australia, and how this may be contributing to a shift in Australian policy. The article concludes with a look at the truce's prospects, and the future of the Australia-China-Taiwan aid-related geopolitics in the South Pacific. 


\section{THE AID TRIANGLE IN HISTORICAL PERSPECTIVE}

Australian involvement in the Pacific Islands began in earnest with the British Empire's colonization of Melanesia. A major rationale driving this encroachment was concern that a hostile foreign power would occupy the region and threaten Australia. This fear was realized in World War II, in which Australia fought alongside the US to dislodge Japanese forces from New Guinea, the Solomon Islands and elsewhere in the South Pacific (see Olson and Shadle 1996, 785, 863). Australia would also increase its involvement from the mid-1970s in part to counter the Soviet Union (Fry 1981, 460). In the late 1970s Australia pushed hard to more fully involve its American ally, but was told that Australia had the "main responsibility" for the South Pacific region (Coutts 2009). Although the sense of imminent threat has decreased after the end of the Cold War, this strong strategic interest in the South Pacific remains (e.g. Australian Government 2009, 42). Australia's military involvement in the region also continues to be an important aspect of its alliance relations with the United States.

Economic interests also drove Australia's early colonial involvement, as did the perceived spiritual and material superiority of its culture to that of the region's indigenous inhabitants. While the racist language and overt paternalism of this period has given way to greater respect for South Pacific autonomy, there is a continued expectation of Australian involvement to alleviate poverty and minimize political violence on the part of the Australian public, the wider Western world and a significant proportion of Pacific Islanders. ${ }^{1}$ For example, Australia's administration of what is now known as Papua New Guinea (PNG) included efforts to develop the territory's governance and economy, seguing into continued deep involvement after independence in 1975 (Nelson 1998).

This history - and Australia's continued proximity and relative wealth compared to the Pacific Islands - has translated into Australia being the region's largest aid donor by a considerable margin. Australia has also played a key part in the region's politics, such as leading the international response to the civil conflicts on the PNG island of Bougainville and in Solomon Islands, and an important role in orchestrating the Western reaction to the 2006 military coup in Fiji.

Colonialism, World War II — and above all — the Cold War, have also shaped the involvement of China and Taiwan in the South Pacific in important ways. Both the KMT and Communist sides fighting against Japan and in the Chinese civil war shared an antipathy to Western imperialism - of which Australia was seen to be a part when noticed at all. In some ways, this attitude would color Taiwan's, and especially China's, current disdain for Australia's claim to speak for the Pacific Islands or otherwise set the agenda in the South Pacific. US intervention in the Taiwan Strait at the start of the Korean War would then deny the Chinese Communists a complete victory over the Chinese Nationalist government. This Republic 
of China (ROC) government on Taiwan continued to compete with the People's Republic of China (PRC) for international recognition as the sole government of China. Although Australia diplomatically recognized the Nationalist government in Taipei, Australia pursued a policy of pressuring each side to accept the indefinite independence of the other, leading to unfriendly relations with both governments (Atkinson 2011).Taipei eventually lost sufficient support for its claim to the China seat in the United Nations (UN) and walked out in 1971. Simultaneously, USChina détente allowed Australia to make concessions to China over Taiwan without damaging its relationship with the US. Australia withdrew diplomatic recognition from the ROC and recognized the PRC in 1972.

During the same late-Cold War period, a new arena for diplomatic competition between Beijing and Taipei for the right to represent "China" emerged as the Pacific Islands gained independence. The two sides swayed the South Pacific governments with aid and other inducements, and at least some South Pacific countries courted both sides. Australia's break with Taiwan had been quite resounding, and it actively supported China's establishment of relations with PNG over competition from Taiwan. Nevertheless, Taiwan's economic success relative to China through the 1970s and 1980s to some extent offset China's greater international weight. By 1988, the ROC had the recognition of four Pacific Island states (so-called "diplomatic allies") - Tonga, Solomon Islands, Nauru and Tuvalu—and the PRC the recognition of five-PNG, Samoa, Fiji, Kiribati and Vanuatu.

The basis of China-Taiwan competition changed with Taiwan's democratization. During Lee Teng-hui's presidency, Taipei increasingly began to act as a government of Taiwan and not China, dropping the condition that Taiwan would only recognize a country if it cut relations with China. Beijing continued to insist that other countries adhere to a "one China policy" and not recognize Taiwan's statehood, and China-Taiwan diplomatic competition maintained much of its pre1988 form despite this fundamental change. Each side would continue to add new diplomatic allies - and occasionally induce one to switch sides - as new Pacific Islands states continued to become independent in the ensuing decade.

The arrival of China-Taiwan diplomatic competition in its South Pacific backyard did not alarm Australia. Britain, France and the US had further lost interest in the South Pacific after the Cold War, increasing regional countries expectations of Australia. As such, Australia welcomed the funds that China and Taiwan made available (Atkinson 2013, 46-47, 165-166).

Australia's attitude towards the involvement of Taiwan and China changed as it became increasingly focused on reforming the Pacific Islands through conditional aid. In common with other neo-liberal or Anglophone donors, Australia has come to view poverty and political instability in developing countries as being due to poor governance (see Breuning and Ishiyama 2003, 252).

Australian aid to the South Pacific region has focused on funding increased 
government capacity, while at times also bypassing - and therefore arguably undermining - the government machinery of recipients in order to deliver aid (see Dietrich 2013; Slatter 2006; Werker 2013, 54, 56). Australia has also used aid on occasion - and the threat to withhold it — as a means to push Pacific Island governments to carry out an Australian-conceived reform agenda. This approach has resulted in a somewhat combative relationship with recipient governments. It also appears to have increased the motivation of the Pacific Islands to seek out sources of aid not conditioned on governance reform, particularly from Japan, China and Taiwan (Wesley-Smith 2013, 367). While all such aid can undermine Australian policy, China's power to help and hurt Australian interests, and Taiwan's relative weakness, would see Australia direct its animosity largely towards Taiwan.

\section{III. "TROUBLEMAKER"TAIWAN}

China's and Taiwan's diplomatic competition would continue, and in some respects intensify, after the Democratic Progressive Party's (DPP) Chen Shui-bian became the president of Taiwan in 2000. The Chinese government would seek to pressure and punish Chen for resisting its unification agenda inter alia through going even more aggressively after Taiwan's diplomatic allies. The Chen Administration would respond with what it called "diplomatic warfare"-actively seeking out new ways to gain and maintain allies while reining in the budgetary excess of the previous government.

Australian involvement was also intensifying. The incoming John Howardled conservative government in 1996 picked up the preceding government's emphasis on reforming the South Pacific. The July 2003 RAMSI intervention in Solomon Islands would then significantly increase this urge to reform the recipients of its aid. The intervention represented a significant increase in Australia's already large investment of resources and prestige in the South Pacific. Australia became motivated to ensure the success of the mission in Solomon Islands and also prevent another costly intervention in the South Pacific in the future. RAMSI also made Australia more fixated on China-Taiwan competition-and Taiwan in particular - as Taiwan had been a significant factor in the deteriorating situation in Solomon Islands.

Australia expressed its increased concern over China-Taiwan competition following the July 2003 election in Kiribati, in which China and Taiwan were accused of funding rival candidates. The Australian high commissioner urged the winner, A note Tong, not to recognize Taiwan. Kiribati and Taiwan nevertheless established diplomatic relations in November 2003. The following year, Australia and Taiwan again faced off in a relatively major dispute over a South Pacific prime minster who had reached out to Taiwan while in a reform dispute with Australia, this time Vanuatu's Serge Vohor (see Atkinson 2010). 
Australia-Taiwan friction culminated in Solomon Islands. In the lead-up to elections in April 2006, a Solomon Islands politician accused Taiwan of funding candidates. Following a post-election riot targeting Honiara's Chinese commercial district that made headlines around the world, the same politician claimed the riot was sparked by popular anger towards Taiwan. Neither of these accusations was supported with evidence, nor have they since been substantiated. Nevertheless, the Australian government and media publicly criticized Taiwan's involvement in Solomon Islands, causing considerable damage to Taiwan's international reputation. Australia's rhetoric drew a negative reaction from Taiwan, which believed Canberra was seeking a scapegoat to deflect from its inability to anticipate or control the riot (Atkinson 2010).

The incident contributed to the Taiwan government's perception of Australia as increasingly pro-China. At least some Chinese appeared to share this view. For instance, Chinese scholars Zhang and Huang (2007) would claim that "many South Pacific countries closely follow Australia's foreign policies ... Australia is of great significance for China's policies. Developing and maintaining a friendly bilateral relationship with Australia may help to contain the power of Taiwan independence."

However, Australian responses to Taiwan remained dependent on overall Australian interests rather than friendship with China per se. A good example was Australia's low key response to Nauru re-establishing relations with Taiwan on 14 May 2005, which was limited to a mere expression of disapproval. The switch occurred after the election of a new government under Prime Minister Scotty. Scotty had a greater commitment to "good governance" than former Prime Minister Harris, and according to the Australian Department for Foreign Affairs and Trade (DFAT 2007) with "the help of the Australian Finance Team in Nauru ... implemented key financial and governance reforms and did much to restore Nauru's international financial reputation." Australia had also maintained since 2001 an "offshore processing centre" on Nauru to hold asylum seekers that had tried to reach Australia by boat. Both of these interests in a friendly relationship with Scotty's government apparently outweighed any incentive to help China prevent Nauru from recognizing Taiwan.

One response to the Chen Administration's predicament of being caught between Australian censure and Chinese suppression would have been to allow the number of Taiwan's diplomatic allies to fall. Influential voices within the DPP had long been skeptical about the need for diplomatic allies, seeing them as anachronistic legacy of the KMT dictatorship. However, constant criticism from the KMT dominated legislature and negative public opinion drowned out assertions from some DPP policymakers that this decline in the ally count was not a problem. The Chen administration accordingly made the ally count more of a priority, especially during its second term. 
Another possible response would have been to "sweeten" an increased focus on transparency and development in Taiwan's aid programs with an increase in the overall amount of aid given to each ally. However, there was opposition within Taiwan to providing aid to countries in the South Pacific and elsewhere - not due to a perception of its harmful effects - but because these governments were seen as greedy and exploitative of Taiwan. This same rationale sustained the opposition KMT-controlled legislature's criticism of President Chen's aid plans in September 2005, and aid funding actually decreased beyond what was already a very low aid effort by DAC standards.

In contrast, China appeared to be raising its aid funding (Hanson 2010, 84), apparently both to increase the pressure on Taiwan and in pursuit of China's other, largely complementary, goals in the South Pacific. The situation became even more difficult for Taiwan when Chinese Premier Wen Jiabao travelled to the South Pacific for the first "China-Pacific Island Countries Economic Development and Cooperation Forum Ministerial Conference" in April 2006. At the conference, China made several significant aid and investment deals with the countries recognizing it in the South Pacific. Mr. Wen described this package as "a 'strategic decision' by one developing nation on behalf of others 'without any political strings attached"' (Zamiska and Dean 2006). This statement was seemingly designed to separate China from increasingly resented Western donors, such as Australia.

Taiwan reacted inter alia with an increased tendency to take risks. A major scandal in mid-2008revealed that in August 2006, Taiwan's Ministry of Foreign Affairs (MOFA) had engaged two businessmen to establish relations with PNG, and wired US\$30 million into their Singapore bank account on 14 September 2006. This money was from MOFA's annual budget, and to be used as "technical aid" for Papua New Guinea to forge official diplomatic ties. PNG's planning minister said he met first with one of the two middlemen and then with Taiwan officials in 2006. According to the minister, Taiwan was "trying to get us into a diplomatic recognition arrangement but we said no." At the end of 2006, MOFA called off the negotiations and requested the middlemen return the money. However, the two men, one a Taiwanese businessman with a US passport and the other a Singaporean, had pocketed the cash and disappeared (Atkinson 2014).

Australia did little to reduce Taiwan's desperation. Australia's cooperation with Taiwan was largely limited to "in-country" discussions between Australia and Taiwan about their respective aid programs in order to avoid overlap. At least in Solomon Islands, this took place at regular donor meetings. Some Taiwan aid funds had also been channeled through trust accounts set up by Australia. Australia's representative to Taiwan, Frances Adamson, began the practice of assisting South Pacific countries in making aid requests to Taiwan. However, Australia had repeatedly ignored Taiwan's overtures for cooperation beyond these levels, anticipating a negative response from China. 
Instead, Australia sought to pressure Taiwan to change without taking on any of the costs with China that would facilitate such a shift. Australia would ask its US ally to "weigh in with Taiwan, and to a lesser extent China, on the need to avoid using assistance in ways that undercut good governance and sustainable development." The US' representative in Taiwan duly met with Taiwan's foreign minister stressing "that Taiwan follow its democratic values in its relations with Fiji and Solomon Islands and stay in close contact with Australia"(Atkinson 2013, 178, 184).

Taiwan was actually quite amenable to Australian pressure. The Bush Administration was leaning more towards China in an effort to enlist Chinese cooperation in the "War on Terror," and President Chen had found himself increasingly isolated as the "troublemaker" in cross-strait relations (e.g. Lee 2010, 242). This had an impact in the South Pacific, with Taiwan becoming more concerned about Australia's capacity - and willingness - to tar its reputation.

Most notably, this motivated Taiwan to reform aspects of its aid program to Solomon Islands. These changes were made despite Taiwan's funding becoming more important to the Sogavare-led Solomon Islands government as its governance dispute with Australia intensified. Significant improvements were made to the controversial - and Taiwan funded-Rural Constituencies Development Fund (RCDF), which provides development money for parliamentarians to spend in their electorates. Perhaps most significantly, when Sogavare turned to Taiwan to help re-arm the Solomon Islands police in the face of stiff opposition from Australia and RAMSI, Australia was able to persuade Taiwan to withdraw its support for the scheme (Atkinson 2009, 63).

China was considerably less sympathetic to Australian policy, as was made starkly evident in Fiji. On 5 December in the face of public opposition from Australia, Commodore Frank Bainimarama took over the government of Fiji in a military coup. When asked by an Australian reporter if he feared sanctions from Australia, interim Prime Minster Jona Senilagakali replied:

You can go ahead ... You did that in 1987, and [we] ... went to South East Asia, and we went to Taiwan, to Japan, we went to Indonesia, Singapore and Kuala Lumpur .... We will ... have no choice but to go to Indonesia, we'll go to Taiwan, we'll go to China to enlist their support. And I'm sure they'll be prepared to do that. My advice is that just leave us alone. Do not introduce economic sanctions on Fiji. I mean, our total life, economic life of Fiji is not dependent fully on Australia. Let me make that very clear to the Australians.

Bainimarama reiterated that Fiji would turn to Asian countries to counteract Australia, saying that though there had not been formal talks with Chinese officials, he "took it for granted that China would always be there" to support Fiji. He added, 
"We have always had close ties with Beijing ... I've already made an official visit there at the invitation of the People's Liberation Army and we've had two senior officers at China's defense college since 2000 ... we'll see how Australia goes in terms of military assistance. If they [Australia] don't help, we'll certainly have to look to other places." He also listed Malaysia, South Korea and Japan as potential sources of support, saying they had not followed Australia, New Zealand, the US and France in cancelling military ties after his coup. However, he left Taiwan off the list and stated, "The Chinese Government came across and said, "we heard you mention Taiwan', so we just wanted to confirm to them that we still recognize the One China policy." It is possible that this expectation of continued support from China, and to a lesser extent other Asian countries, emboldened Bainimarama to ignore Australian threats and carry out the coup (all quotes from Atkinson 2013, 190).

As the Fijian military government had expected, China did shrug off opposition from Australia and met Fijian expectations of support (see below). In contrast, Taiwan agreed to the US and Australia's request to halt its direct payments to the office of Fiji's prime minister after the coup.

\section{MA YING-JEOU'S “DIPLOMATIC TRUCE"}

Australia's influence in the South Pacific and leverage with the US meant that its pressure was having an impact in Taipei. Yet as long as Taiwan's government and voters continued to see official diplomatic relationships with the small countries in the South Pacific and elsewhere as vital to the national interest, Taiwan could not strictly condition aid to its South Pacific allies if that meant they would break diplomatic relations and recognize China. Simultaneously, the lack of domestic political support for raising the aid budget meant Taiwan would continue to employ risky - even scandalous - tactics, and the controversy with Australia could worsen. The Chen Shui-bian administration was thus caught between the ally count, a limited budget and Australian criticism.

This alignment of KMT, Chinese and Australian pressure on Chen Shui-bian and the DPP would continue to be important well after Chen left office. Beijing and the KMT had a shared interest in not just defeating the DPP candidate in the 2008 presidential election, but also in reducing the DPP's ability to win elections in general. The tacit "diplomatic truce" the Ma Ying-jeou Administration was able to maintain with China after assuming office on 20 May 2008 can be seen as one element in this agenda. It should be understood as a joint KMT and Chinese government attempt to demonstrate to Taiwan's voters the KMT's superior ability to maintain the ally count, reduce foreign affairs expenses and improve relations with Western democracies such as Australia.

As such, reforming Taiwan's aid programs is only a priority for the Ma 
Administration to the extent that it helps achieve these goals. Taiwan's use of the truce to move towards DAC norms has therefore been limited and there remains considerable continuity with past practices. In contrast to Australia, which rates highly on most measures of donor transparency (Ghosh and Kharas 2011, 1924), the government's handling of aid as a foreign policy tool is still largely opaque and unaccountable. The continued decline in Taiwan's aid budget is one example of how further adhering to DAC norms is relatively unimportant for the Taiwan government. However, it should be remembered that in at least one important respect-providing the majority of its aid as direct budget support-Taiwan's aid program arguably already exceeds most donors in what some development aid specialists see as an important element of best practice (for the putative benefits of budget support see Koeberle et al. 2006).

Rather than greater socialization to DAC norms, the reforms that the Ma Administration introduced after the truce have concentrated on reducing scandal. President $\mathrm{Ma}$ is said to have told his ambassadors that if any are "caught "check booking' then they are done" (Atkinson 2014). Indeed, Taiwan's representative to Fiji, Victor Chin, would be impeached for "forgery with the intention of misappropriating public funds in order to buy expensive items for the wives of several highranking Fijian government officials" (Yeh 2013). However, Chin's affair with a Japanese diplomat was probably the most significant factor leading to his downfall.

Taiwan has also become less tolerant of allied governments bringing Taiwan's aid into disrepute. Given the extra scrutiny of Taiwan's relationship with Solomon Islands that Australia's involvement entails, it is not surprising that the most remarkable example of this new dynamic involved Solomon Islands' Prime Minister Danny Phillip. Taiwan Ambassador Roy Wu reportedly refused to tolerate Phillip's misuse of roughly US\$1.5 million of development funding, apparently contributing to Phillip's unseating. A further significant change is that the RCDF cherished by many Solomon Islands parliamentarians was renamed in 2011 and is now dispersed through a consolidated account. However, Taiwan's leverage over its diplomatic allies still has limits and Taiwan may not be so stringent when there is less risk of scandal. This greater ability to respond to pressure from donor countries such as Australia or opposition groups within recipient polities appears to have boosted Taiwan's international reputation.

Taiwan's reputation also seems to have improved due to the nature of news media coverage. Simply halting the churn of diplomatic allies between China and Taiwan greatly reduced both Western and Taiwanese media interest in Taiwan's role in developing countries. This reduced scrutiny effectively lowered the bar for reform. It also allowed the Ma Administration to set the news agenda in a way that focused attention on its aid reform rhetoric.

The Ma Administration's effort to improve Taiwan's reputation was directly aimed at Australia to a significant extent. Ma Ying-jeou visited Australia as the 
presumptive KMT presidential candidate in May 2006, promising to solve Australia's problem of China-Taiwan rivalry in the South Pacific by developing a "modus vivendi with the mainland on the international space." President Ma specifically told The Australian that Australia's concern about Taiwan's role in the South Pacific was "a very important element in changing [Taiwan's] foreign policy" to bring about this tacit truce. Ma also stated, "According to my contact with Australian friends, by and large your people seem to be satisfied with what we have been doing, particularly over our dealings with South Pacific countries." Tangible proof was provided when Ma was able to visit RAMSI headquarters during his trip to Solomon Islands. Australia's government aid agency, A us AID, also agreed to establish an annual dialogue with an important foreign aid agency in Taiwan, the ICDF. Vice Foreign Minister Chang Hsiao-yueh was further welcomed in Australia to discuss the Pacific Islands (Atkinson 2013, 185-186, 192).

This was an important foreign policy accomplishment for President Ma. In his September 2008 address to the legislature, Taiwan's foreign minister reported "Taiwan's flexible diplomacy has won support from New Zealand and Australia, which have expressed interest in cooperating with Taiwan in its humanitarian projects in the South Pacific region" (MOFA 2010). However, neither this Australian approbation - nor halting the decline in the number of diplomatic allies or the reduction in the aid budget - would stop Ma Ying-jeou from becoming deeply unpopular with Taiwan's voters. Indeed, Ma's opinion poll ratings would plunge significantly below the lows reached by Chen Shui-bian (Wang 2013).

\section{THE TRUCE FROM CHINA'S POINT OF VIEW}

Unlike the multiple policy goals of the Ma Ying-jeou Administration, China's participation in the truce is focused squarely on its Taiwan policy. China extends the truce as a "benefit" to Taiwan in return for progress towards unification, much like it provides other incentives such as a preferential trade agreement (see for example Cabestan 2010). Beijing appears to seek concrete concessions while President $\mathrm{Ma}$ is in power in order to tie the hands of future - and perhaps less friendly - administrations. Chinese leader Xi Jinping recently reminded the Ma Administration that "ensuring the peaceful development of relations" requires that "the issue of political disagreements that exist between the two sides must reach a final resolution, step by step, and these issues cannot be passed on from generation to generation" (Pomfret et al. 2013). This sense of urgency coexists with the need to not press Ma to the point that it results in too great a public backlash in Taiwan.

This policy balancing act is the reason that Beijing has continued to insist that the truce remains tacit. An explicit agreement with Taipei would undermine Beijing's principle that it is the sole national government for Taiwan. It would also make it more difficult for Beijing to withdraw the truce at a later stage if it 
perceives that Taiwan is not progressing towards unification.

China's posture towards Taiwan in the South Pacific conforms to this wider policy context. Beijing has refused to tolerate any suggestion that the truce weakens its claim to Taiwan. China insisted that a Taiwan diplomat be removed from a post-Pacific Islands Forum session in the Marshall Islands, and a Chinese delegate refused to participate in a panel session due to the presence of a ROC flag and a plaque commemorating the Taiwan-funded construction of the forum venue (Pacnews 2013). According to one report, China invited Taiwan's South Pacific diplomatic allies to both attend the November 2013 "Second China-Pacific Island Countries Economic Development and Cooperation Forum" in Guangzhou and access a US\$1 billion pool of concessional financing set aside for the Pacific Islands (Sasako 2013). However, at least according to official reports, only countries with diplomatic relations with China attended the forum and were given access to the pool of credit (MFA 2013).

There is no indication that China has reduced its aid to the region, and some indication that it may have continued to increase it (e.g. Hayward-Jones 2013, 11). For example, the additional US\$1 billion in concessional financing announced in Guangzhou was more than double the amount announced during Wen Jiabao's forum in 2006. The form this aid takes also appears to be changing, with a greater proportion of Chinese aid apparently being delivered as loans (Bräutigam 2009, 6).

China appears confident in its position vis-à-vis Taiwan in the South Pacific. Notably, the Chinese leadership assigned the relatively low-ranked Vice Premier Wang Yang to host the forum, effectively downgrading engagement with the Pacific Islands governments. Hence, there is little reason to believe that concern about competition from Taiwan drives the increases in Chinese aid or the shift towards a greater proportion of loans. Nevertheless, the direction of Chinese aid allows China to maintain a strong position to resume diplomatic competition if it decides to cancel the truce.

\section{GROWING AUSTRALIA-CHINA FRICTION?}

In contrast to warming Australia-Taiwan relations in the South Pacific, the truce appears to have actually exacerbated friction between Australia and China. As Sullivan and Renz $(2012,4)$ note, the reduced focus on checkbook diplomacy has increased the salience of other aspects of Chinese involvement. Moreover, because Australia and China no longer have a common antagonist in Taiwan, the contradictions between the two appear to have become more pronounced.

Fiji remains the starkest illustration of this divergence between Australia and China. China has continued to provide support to the regime despite repeated Australian attempts to co-opt China to its policy of isolating the Bainimarama government (Pearlman 2009). This support has reportedly included increased training 
for Fijian military officers. China also ignored opposition from Australia and New Zealand, and sent China's then Vice-President (and now leader) Xi Jinping to Fiji in 8-9 February 2009. The Chinese downplayed the visit as a "stopover" on the way to Latin America. He nevertheless signed several development assistance deals that were pledged during Wen Jiabao's visit in April 2006, and met with President Iloilo and Prime Minister Bainimarama. Australian officials initially thought the "value of the development deals was more symbolic than economic" (WikiLeaks 2009a). However, a New Zealand official later described them as “'massive' and potentially very destructive given the poor capacity of small South Pacific nations to repay large loans." Australia and New Zealand thought China was "shamed" by the Xi Jinping transit and "that their [Chinese Ministry of Foreign Affairs] contacts assured them that such lack of coordination on regional issues would not happen again" (WikiLeaks 2009b).

In fact, Beijing would not reduce its support for the Fijian government or align its policy with Australian interests. Senior Chinese leader Wu Bangguo visited Fiji in September 2012, and reportedly handed over a US\$112 million concessional loan. Wu also criticized Australia and New Zealand's approach to Fiji as "bullying" (Government of Fiji 2012):

We are opposed to the bullying of big region strong countries over the small or weak countries. The Chinese are opposed to the imposition of isolation by some countries over Fiji, and China will continue to talk to relevant countries to engage in constructive and equal footing engagement and on the basis of equality.

Officials at China's Ministry of Foreign Affairs (MFA) had underlined this divergence between Australian and Chinese views on Fiji to US diplomats in 2009. According to Chinese officials, it was "western-led efforts to push for political reform in Fiji were part of Fiji's underlying problem" and that China "as a developing country and regional leader, had unique insights into Fiji's political needs" (WikiLeaks 2009b).

It is important to note that it is Australia and New Zealand - not China-that appear to be more out of step with Pacific Islands governmental opinion. One reason China has not accommodated Australia over Fiji is that meeting these South Pacific expectations remains more important for China than responding to Australian concerns. For example, Tarte $(2010,129)$ views China's support for Fiji as indicating that "China may not want to be too much out of step with the position on Fiji taken by the Pacific Islands Forum."

\section{CONTENDING CONCEPTIONS OF AID}

This apparent effort to at least partly meet Pacific Island expectations is part of China's overall conception of aid and development, a conceptualization that continues to diverge significantly from that of Australia. Some see China's aid 
from more like that of the traditional donors. However, as Varrall $(2013,251)$ notes, Chinese foreign policy thinking posits China as target of a hostile West that seeks to sow fear of China in the developing world. Aid is viewed as "a useful means of counteracting this fear." Also, China's commitment to providing overseas assistance "China's way" is deeply and passionately held, and it is unlikely to identify with, and move towards, DAC norms in the immediate future (Varrall 2013, 254).

Even if or when China eventually joins DAC there will likely still be significant differences between Chinese and Australian aid practices. For instance, Chinese and Japanese aid have important commonalities, such as the emphasis on prestige and friendly relations with developing countries, the involvement of politicallyconnected domestic enterprises in initiating and dispersing aid, and the link with trade and investment policies (see Shino 2013, 102; Yasutami and Wang 2013, 127; Filer 2013; Bräutigam 2009, 18). And while Japan is member of DAC, it is generally viewed as having a very different aid approach to Australia. For example, Ghosh and Kharas $(2011,1924)$ rank Australia $2^{\text {nd }}$ and Japan $23^{\text {rd }}$ out of 31 bilateral and multilateral donor agencies in terms of overall transparency. Tarte $(2005,242-$ 243) notes that while Australia "emphasizes economic and public sector reform in its [South Pacific] aid program [...] the aid [Japan] provides in the form of goods, services and infrastructure is not always conducive to the goals of the regional reform agenda." Notably, Australia has taken issue with continued Japanese aid to the Fiji after the coups in 1987 and 2000, Japan's use of aid to buy votes in the International Whaling Commission, and its impact on fisheries governance (see Tarte 2005, 249-250; Petersen 2003). This experience with Japan suggests that the significance of any putative Chinese movement towards DAC norms should not be overstated.

It is therefore not surprising that China continues to resist an important DAC norm, reflected in the Paris Declaration's call for greater aid cooperation (socalled "harmonization").

In some ways, China has made the South Pacific the region where it has engaged most with other development partners. Nevertheless, it has continued to stop short of substantial cooperation with Australia and New Zealand on aid. Most notably, Australia and New Zealand sought unsuccessfully to persuade China to join the "Cairns Compact," which they see as encouraging "greater cooperation and transparency in South Pacific aid projects." Lantaigne (2013b, 33) quotes an American official explaining, "Our Chinese friends politely said, frankly, we will do our own investment and we will do our own quid pro quo in a bilateral context." China claims "sincerity in helping [recipient] countries to achieve development" (MFA 2013), and whether this Chinese resistance to harmonization with other donors is good or bad remains in dispute (Yasutami and Wang 2013, 129; Winters 2012, 316; Sato et al. 2010, 18). 


\section{COMPETITION FOR INFLUENCE?}

However, the divergence between Australia and China is possibly deeper than a difference in opinion over the role of aid in development. Again, a comparison with Japan is illustrative. Japan and Australia are both democracies and important US allies in the Asia-Pacific region. This was a significant factor in Japan bending to Australian pressure and excluding Bainimarama from its triennial summit-level meeting with Pacific Islands leaders (PALM). This occurred despite strong Japanese misgivings at the increased influence that would accrue to China as a result (Tarte 2012). In contrast, China resists democracy as a universal principle and the network of US alliances, and has continued to be indifferent to important Australian policies in the South Pacific.

Notably, Australia's championing of international action to promote democracy appears potentially to be in direct competition with Chinese policy. According to Yang Jian $(2011,310)$, China has an interest in supporting Fiji, because China, too, has been labeled a "rogue state" and the target of Western sanctions. In addition, the recent memo issued by senior Chinese leaders to Communist Party cadres referred to as Document No. 9 enumerated seven threats to party rule, including: "Western constitutional democracy," "universal values," media independence and civil society, and "neo-liberalism" (Buckley 2013). An international aspect of this opposition to what is construed as Western governance was verbalized in a recent address by Chinese Ambassador to the UK, Liu Xiaoming. Liu (2013) stressed that China advocates a world of diverse civilizations and each country is entitled to choose its own mode of development according to its own circumstances.

China and Australia also have potentially opposing security interests in the South Pacific. China opposes US predominance as a general foreign policy principle, and is developing capabilities designed to counter US military superiority in China's near seas (Chase 2011). This is in direct contrast to Australia, which supports the continued pre-eminence of US power in Asia. Evaluating the extent to which this wider strategic dynamic shapes Australia-China relations in the South Pacific is not straightforward due to what Zhang $(2007,372)$ describes as "the opaque nature of its political system, secretive nature of its foreign policy-making process and general lack of information." Further complications are that the South Pacific is relatively strategically unimportant to China, and that China must balance any strategic gains in the South Pacific against the strategic benefits of separating the US from its Australian ally. It is in this context that Han Feng claimed that "If we [China] were to compete seriously for political influence in the South Pacific, the first casualty would be our relations with Australia and New Zealand, and we do not want that" (Ford 2012). As such, the weight that should be given to any strategic motives behind Chinese involvement in the South Pacific remains contentious. 
Nevertheless, the issue of wider competition between China and the US and its allies does appear to be one driver of friction between Australia and China. Lanteigne $(2013 b, 27)$ finds evidence of "low-level" or "soft" "balancing competition" in the South Pacific between China on one hand and the US and its Australian ally on the other. While perhaps not the mainstream view, there are some at least some commentators in China that view the South Pacific as an arena of major power competition. For example, Zhang Guihong describes the South Pacific as "strategically important [...] gateway of the Pacific Ocean [where] a number of observatories can be set up [...] which will be important for China's future satellite and space technologies" (quoted in Powles 2009, 22). Also, vicedirector of the School of International Studies at Renmin University, Jin Canrong (2009) claimed that "China's influence over the South Pacific has been increasingly steady[sic] ... The US may have evaluated that Australia alone is no longer enough to hold China at bay." Finally, the fact that the US has clearly stated that it is in competition with China in the South Pacific further lends some weight to the suggestion that this competition is real(see Quinn and Whitesides 2011).

In any case, it is clear that "China's influence in the South Pacific has grown substantially in the past one or two decades" (Yang 2010, 259) and that "China's emergence as a significant economic and diplomatic actor in the South Pacific has come at some cost to US, Australia, and New Zealand influence" (Saunders 2010, 249). It is also apparent that Australian policymakers have responded with steps to shore-up Australian influence in the South Pacific. According to a leaked US diplomatic cable, Australian Prime Minister Kevin Rudd was "especially concerned with Chinese influence in the Pacific and sees Australian leverage ebbing thanks to massive Chinese aid flows" (Wikileaks 2008). Rudd subsequently announced plans to almost double Australia's aid budget by 2016, with an increased focus on the South Pacific (Dziedzic 2011). The recently elected conservative government halted increases to Australia's aid budget, perhaps suggesting that competition with China is less of a priority. However, the new government's move to bring Australia's aid agency back under the umbrella of DFAT points to a renewed emphasis on aligning aid with Australia's foreign policy interests.

China also appears to have perhaps prompted a shift away from a policy of reforming governance. In August 2012, Australian Foreign minister Bob Carr declared, "Australia and New Zealand have got to live with the fact that China will want to deliver aid in this part of the world [and] there is nothing we can do to stop it. It's a fact of life" (Kerin 2012). The 2013 Australian Defense White Paper (Australian Government 2013a, 15) then suggested that:

As Australia plays a central role in the South Pacific, we will need to continue to be a source of economic, diplomatic and, if necessary, military support. But we recognize that attitudes to our role are changing. While Australia 
provides half the region's total development aid and will be significantly increasing this contribution, the growing reach and influence of Asian nations opens up a wider range of external players for our neighbors to partner with. Australia's contribution to this region may well be balanced in the future by the support and assistance provided by other powers.

The US appears to have played a role in shaping this shift, and has specifically urged the Australian government to stop pushing the Pacific Islands closer to China (see Cheng 2012; Davis 2012).

This pressure, combined with the realization that Australia's approach to Fiji has not been very effective to date, may have contributed to the evident easing of Australian policy towards the Bainimarama. For example, Australia and New Zealand announced on 30 July 2012 that they would restore diplomatic relations with Fiji, and ease the sanctions they had imposed on the regime (Australian Government 2013b). Presumably, any softening of Australia's approach to governance and greater wariness of China would temper the Australian response to a future Taiwan president who resumes "checkbook diplomacy" if China withdraws the truce.

\section{LOOKING AHEAD}

This apparently shifting Australian attitude is possibly an indication that the factors which came together to create and sustain the tacit "diplomatic truce" are no longer so relevant. Another sign that the truce may be increasingly anachronistic is that controversies surrounding the Ma Administration's governance and relationship with Beijing have completely overshadowed the issues of aid and diplomatic allies in Taiwan's domestic and international politics. This means that the truce will presumably be less salient to the next Taiwan president.

Still, if or when China cancels the truce, the future Taiwan president-either KMT or DPP - will have to make a new calculation about the relative importance of maintaining the number of South Pacific diplomatic allies, friendly relations with Australia, and low aid spending. The Taiwan government is enjoying the reduced international criticism of Taiwan's aid program. A future Taiwan president may choose to tolerate a reduced number of diplomatic allies in return for maintaining the positive gains to Taiwan's international reputation and relationship with Australia. It is possible that as long as the Taiwanese public perceives China to be the status quo-changing aggressor, they will ignore efforts to sensationalize the falling number of diplomatic allies. Given Taiwan's consistent efforts to reduce its aid spending, it seems unlikely that aid funding will increase much, if at all, beyond existing levels in the foreseeable future.

China's commitment to the truce remains to be seen. The truce is more likely 
to hold if the KMT retains the presidency. However, Beijing may withdraw this form of support if future KMT presidents do not make sufficient concessions to its unification agenda. Beijing is much less likely to get these concessions from a DPP president, and thus presumably the truce is more likely to be withdrawn if the KMT loses power. However, some close to the DPP believe that the leadership in Beijing is reluctant to alienate Taiwanese voters through a return to diplomatic competition. If this is the case, the truce may have more staying power.

It seems likely that China will remain uninterested in changing its aid policy and cooperating with Australia in the South Pacific to the degree Australia would like. If Australia has indeed softened its approach to reforming the Pacific Islands, then this will continue. In one respect, this can be seen as a growing convergence of Australia's and China's aid policy approaches, with Australia adopting a modicum of China's emphasis on maintaining friendly relations with Pacific Islands governments. However, there is also some indication that the need to better compete against China for influence in the South Pacific is one driver of this shift. In sum, and though the durability of the diplomatic truce remains to be seen, the signifycant mutual impact of the aid programs of Australia, China and Taiwan, and their contestation over aid and the South Pacific, looks set to continue.

\section{REFERENCES}

Atkinson, Joel. 2009. Big Trouble in Little Chinatown: Australia, Taiwan and the April 2006 Post-Election Riot in Solomon Islands. Pacific Affairs 82(1): 47-65. Atkinson, Joel. 2010. China-Taiwan Diplomatic Competition and the Pacific Islands. The Pacific Review 23(4): 407-427. DOI: 10.1080/09512748.2010.495998.

Atkinson, Joel. 2011. Australian Support for an Independent Taiwan Prior to the Recognition of the People's Republic of China. Australian Journal of Politics and History 57(1): 68-85.

Atkinson, Joel. 2013. Australia and Taiwan: Bilateral Relations, China, the United States, and the South Pacific Leiden and Boston: Brill.

Atkinson, Joel. 2014. Aid in Taiwan's Foreign Policy: Putting Ma Ying-jeou's Aid Reforms in Historical Perspective. The Pacific Review 27(3): 409-431. DOI: $10.1080 / 09512748.2014 .909524$.

Australian Government. 2009. Defending Australia in the Asia Pacific Century: Force 2030. Canberra: Commonwealth of Australia.

Australian Government. 2013a. Defence White Paper 2013. Canberra: Commonwealth of Australia.

Australian Government. 2013b. Foreign Minister's Trilateral Meeting: Joint statement: Senator the Hon. Bob Carr, Ratu Inoke Kubuabola,The Hon Murray McCully. http://www.foreignminister.gov.au/releases/2012/bc_mr_120730. html: Minister for Foreign Affairs. 
Bräutigam, Deborah. 2009. The Dragon's Gift: the Real Story of China in Africa. New York: Oxford University Press.

Breuning, Marijke and John T. Ishiyama. 2003. Donor Characteristics and the Dispersion of Foreign Assistance. International Politics 40(2): 249-268.

Buckley, Chris. 2013. China Takes Aim at Western Ideas. New York Times, 19 August, A1. http://www.nytimes.com/2013/08/20/world/asia/chinas-new-lea dership-takes-hard-line-in-secret-memo.html?_r=0.

Cabestan, Jean Pierre. 2010. The New Détente in the Taiwan Strait and Its Impact on Taiwan's Security and Future: More Questions than Answers. China Perspectives 3: 22-33.

Chase, Michael S. 2011. Chinese Suspicion and US Intentions. Survival 53(3): 133-150.

Cheng, Guangjin. 2012. Clinton Visit Raises Concerns. China Daily. Retrieved from http:/www.chinadaily.com.cn/world/2012-08/29/content_15714079.htm.

Coutts, Geraldine. 2009. Australia Secret Cabinet Papers Revealed. Australian Broadcasting Corporation. Retrieved from http://www.radioaustralia.net.au/ programguide/stories/200901/s2457984.htm.

Davis, Graham. 2012. Better than this? Bainimarama Blames Rudd's 'Pacific Neglect' for Regional Power Vacuum. http://pacific.scoop.co.nz/2012/02/bai nimarama-blames-rudds-pacific-neglect-for-regional-power-vacuum/\#more16090: Pacific Scoop.

DFAT. 2007. Republic of Nauru Country Brief. Australian Government.

Dietrich, Simone. 2013. Donor Political Economies and Foreign Aid Delivery. Research Frontiers in Foreign Aid, Princeton University, 26-27 April.

Dziedzic, Stephen. 2011. Rudd Announces Foreign Aid Overhaul. http://www.abc. net.au/news/2011-07-06/rudd-announces-foreign-aid-overhaul/2784526: Aus tralian Broadcasting Corporation.

Filer, Colin. 2013. Asian Investment in the Rural Industries of Papua New Guinea: What's New and What's Not?Pacific Affairs 86(2): 305-326.

Ford, Peter. 2012. Clinton to Cook Islands: US cares (more than China).Christian Science Monitor. Retrived from http:/www.csmonitor.com/World/Asia-Paci fic/2012/0831/Clinton-to-Cook-Islands-US-cares-more-than-China.

Fry, Gregory E. 1981. Regionalism and International Politics of the South Paci-fic. Pacific Affairs 54(3): 455-484.

Ghosh, Anirban and Homi Kharas. 2011. The Money Trail: Ranking Donor Transparency in Foreign Aid.World Development 39(11): 1918-1929.

Government of Fiji. 2012. Statement by H. E. Wu Bangguo, Chairman of the Standing Committee of the National People's Congress of the People's Republic of China, at the Bilateral Meeting with the Prime Minister Commodore Voreqe Bainimarama. http://www.fiji.gov.fj/index.php?option=com_content\&view= article\&id=6872: statement-by-he-wu-bangguo-at-the-bilateral-meeting-wi 
th-pm-bainimarama\&catid=50: speeches\&Itemid $=168$.

Hanson, Fergus. 2010. China: Stumbling through the Pacific? In Looking North,

Looking South: China, Taiwan and South Pacific, edited by Anne-Marie Brady, Singapore: World Scientific: 83-112.

Hayward-Jones, Jenny. 2013. Big Enough for All of Us: Geo-strategic Competition in the Pacific Islands. Sydney: Lowy Institute for International Policy.

Kerin, John. 2012. Carr softens line on secretive Chinese aid. http://www.afr.com/ p/national/carr_softens_line_on_secretive_chinese_yNMqTrSjtyfZJBxTlFpu TN: The Australian Financial Review.

Koeberle, Stefan, Zoran Stavreski, and Jan Walliser, eds. 2006. Budget Support as More Effective Aid?: Recent Experiences and Emerging Lessons. Washington, D.C.: The World Bank.

Lee, Wei-chin. 2010. Sound and Fury: the United States-Taiwan Relations Under Chen Shui-bian in the 2000s. In Taiwan's Poltics in the 21st Century: Changes and Challenges, edited by Wei-chin Lee, 227-264. Singapore: World Scientific. Liu Xiaoming. 2013. Liu Xiaoming: Zhonguo Waijiao Youge Shijie Meng [Liu Xiaoming: China's Diplomacy Has a World Dream]. Political China. Retrieved from http://www.politicalchina.org/NewsInfo.asp?NewsID=228678.

MFA. 2013. Wang Yang Meets with Foreign Officials Attending Second ChinaPacific Island Countries Economic Development and Cooperation Forum. http://www.fmprc.gov.cn/eng/zxxx/t1097533.shtml: Government of the People's Republic of China.

MOFA. 2010. Foreign Policy Report, 7th Congress of the Legislative Yuan, 6th Session. http://www.mofa.gov.tw/webapp/ct.asp?xItem $=51262 \& \mathrm{ctNode}=1877$ \&mp=6: Republic of China (Taiwan) Government.

Nelson, Hank. 1998. Papua and New Guinea. In Paul Hasluck in Australian History: Civic Personality and Public Life, edited by Tom Stannage, Kay Saunders and Richard Nile, 152-169. St Lucia, Q1d University of Queensland Press.

Olson, James S. and Robert Shadle, eds. 1996. Historical Dictionary of the British Empire. Westport, CT: Greenwood Press 2.

Pacnews. 2013. Marshall Islands expects reprimand from Taipei over diplomatic spat at the Forum Leaders meeting. Island Business. Retrieved from http:// www.islandsbusiness.com/news/marshall-islands/2786/marshall-islands-exp ects-reprimand-from-taipei-ove/.

Pearlman, Jonathan. 2009. China's 'Chequebook Diplomacy' in Fiji Under Fire. Sydney Morning Herald. Retrieved from http://www.smh.com.au/world/ chinas-chequebook-diplomacy-in-fiji-under-fire-20090420-acpr.html.

Petersen, Elizabeth. 2003. The Catch in Trading Fishing Access for Foreign Aid. Marine Policy 27: 219-228.

Pomfret, James, Ben Blanchard, and Nick Macfie. 2013. China's Xi says Political Solution for Taiwan Can't Wait Forever. Reuters. Retrieved from http://www. 
reuters.com/article/2013/10/06/us-asia-apec-china-taiwan-idUSBRE99503Q 20131006.

Powles, Michael. 2009. China's Rise: A Pacific View. Asia New Zealand Foundation. Retrieved from www.asianz.org.nz.

Quinn, Andrew and John Whitesides. 2011. Clinton says China Seeks to Outflank Exxon in Papua New Guinea. http://www.reuters.com/article/2011/03/02/uschina-usa-clinton-idUSTRE7215UV20110302: Reuters.

Sasako, Alfred 2013. China offers. Solomon Star. Retrieved from http://www.solo monstarnews.com/news/national/17764-china-offers.

Sato, Jin, Hiroaki Shiga, Takaaki Kobayashi, and Hisahiro Kondoh. 2010. How do 'Emerging' Donors Differ from 'Traditional' Donors? An Institutional Analysis of Foreign Aid in Cambodia. Tokyo: JICA Research Institute.

Saunders, Phillip C. 2010. Chinese Foreign Policyin Asia: Implications for the South Pacific. In Looking North, Looking South: China, Taiwan, and the South Pacific, edited by Anne-Marie Brady, Singapore: World Scientific: 227-258.

Shino, Watanabe. 2013. Donor's Impact on China: How Have Major Donors Affected China's Economic Development and Foreign Aid Policy? In The Rise of Asian Donors: Japan's Impact on the Evolution of Emerging Donors, edited by Sato Jin and Shimomura Yasutami, Oxon: Routledge: 87-113.

Slatter, Claire. 2006. Treading Water in Rapids? Non-Governmental Organisations and Resistance to Neo-Liberalism in Pacific Island States. In Globalisation and Governance in the Pacific ISlands, edited by Stewart Firth, 23-42. Canberra: Australian National University E-Press.

Sullivan, Jonathan and Bettina Renz. 2012. Representing China in the South Pacific. East Asia 29(4): 377-390.

Tarte, Sandra. 2005. Japan's ODA in the Pacific Island States. In Japan's Foreign Aid: Old Continuities and New Directions, edited by David Arase, Abingdon, Oxon: Routledge: 235-252.

Tarte, Sandra. 2010. Fiji's 'Look North' Strategy and the Role of China. In China in Oceania: Reshaping the Pacific?, edited by Terence Wesley-Smith and Edgar A. Porter, New York and Oxford: Berghahn Books: 118-132.

Tarte, Sandra. 2012. Japan's Pacific Islands Diplomacy at a Crossroads.East Asia Forum. Retrieved from http://www.eastasiaforum.org/2012/05/24/japan-spacific-islands-diplomacy-at-a-crossroads/.

Varrall, Merriden. 2013. Chinese Views on China's Role in International Development Assistance. Pacific Affairs 86(2): 233-256.

Wang, Chris. 2013. Ma's Approval Rating Plunges to 9.2 Percent http://www.tai peitimes.com/News/front/archives/2013/09/16/2003572243: Taipei Times.

Werker, E. 2013. Chapter 5-Political Economy of Foreign Aid, Bilateral. In Handbook of Safeguarding Global Financial Stability, edited by Gerard Caprio, 47-57. San Diego: Academic Press. 
Wesley-Smith, Terence. 2013. China's Rise in Oceania: Issues and Perspectives. Pacific Affairs 86(2): 351-372.

Wikileaks. 2008. 08CANBERRA59: Rudd's Foreign Policy-An Overview. http:// wikileaks.org/cable/2008/01/08CANBERRA59.html.

WikiLeaks. 2009a. 09BEIJING383: Australia and New Zealand Demarche PRC on Fiji Visit. http://wikileaks.org/cable/2009/02/09BEIJING383.html.

WikiLeaks. 2009b. 09BEIJING1679: PRC/South Pacific: International Isolation of Regime in Fiji an Opportunity for China. http://wikileaks.org/cable/2009/06/ 09BEIJING1679.html.

Winters, Matthew S. 2012. The Obstacles to Foreign Aid Harmonization: Lessons from Decentralization Support in Indonesia. Studies in Comparative International Development 47: 316-341.

Yang, Jian. 2010. The South Pacific in China's Grand Strategy. In Looking North, Looking South: China, Taiwan, and the South Pacific, edited by Anne-Marie Brady, Singapore: World Scientific: 259-282.

Yang, Jian. 2011. China in Fiji: Displacing Traditional Players? Australian Journal of International Affairs 65(3): 305-321.

Yasutami, Shimomura, and Ping Wang. 2013. The Evolution of 'Aid, Investment, Trade Synthesis' in China and Japan. In The Rise of Asian Donors: Japan's Impact on the Evolution of Emerging Donors, edited by Jin Sato and Yasutami Shimomura, Oxon.: Routledge: 114-132.

Yeh, Joseph. 2013. Control Yuan impeaches ex-envoy to Fiji for graft. The China Post. Retrieved from http://www.chinapost.com.tw/taiwan/national/nationalnews/2013/09/04/388050/Control-Yuan.htm.

Zamiska, Nicholas, and Jason Dean. 2006. Treasure Islands: China and Taiwan Spar over Friends in Small Places. Wall Street Journal. Retrieved from http:// www.news.vu/en/news/InternationalMediaCoverage/060509-China-and-Tai wan-Spar-Over-Vanuatu.shtml.

Zhang Lu and Huang Ji. 2007. Daguo Zhoubian Zhanlue Zhong de Aodaliya: Dazhoubian Zhanlue Linian yu Waijiao Mouhua de Xintansuo [Australia in China's Peripheral Strategy]. Contemporary International Relations 2: 40-45. Zhang, Yongjin. 2007. China and the Emerging Regional Order in the South Pacific. Australian Journal of International Affairs 61(3): 367-381. 


\section{ENDNOTES}

${ }^{1}$ Regional public opinion on this is mixed. Respondents to a poll conducted in PNG and Solomon Islands by The Pacific Institute of Public Policy stated that Australia was their country's "best partner" by a considerable margin. However, $32.9 \%$ respondents from Vanuatu considered China to be the best partner, ahead of Australia at 14.1\% (Pacific Institute of Public Policy 2011). A clear majority $(63 \%)$ of respondents to a Lowy Institute poll either strongly disagreed $(44 \%)$ or partly disagreed (19\%) with the approach taken by the Australian government towards the Fiji government in response to the 2006 coup. Thirty-six per cent of respondents either strongly agreed $(21 \%)$ or partly agreed (15\%) with the Australian approach (Hayward-Jones 2011). 